\title{
Tools of Information and Communication Technologies in Ecological Marketing under Conditions of Sustainable Development in Industrial Regions (Through Examples of Poland and Ukraine)
}

\author{
Aleksandra Kuzior and Alla Lobanova *(1) \\ Department of Applied Social Sciences, Faculty of Organization and Management, Silesian University of \\ Technology, 41-800 Zabrze, Poland; aleksandra.kuzior@polsl.pl \\ * Correspondence: alla.lobanova@polsl.pl
}

Received: 15 September 2020; Accepted: 8 October 2020; Published: 12 October 2020

\begin{abstract}
This scientific work analyzes the current state and problems of implementing the concept of sustainable development in industrial regions, in particular, in Poland and Ukraine. Emphasis is placed on slowing down the implementation of the main provisions of this doctrine, in particular, the violation of environmental requirements and non-compliance with ecological standards by industrial enterprises. The aim of the article is to find effective innovative tools for intensifying the process of implementing the strategy of sustainable development in industrial regions. The paper uses theoretical methods-analysis and synthesis, formalization, hypothetical-deductive modeling, mental modeling, systematization and generalization-as well as empirical: observation, description and comparison. The main result of the work is the substantiation of the scientific idea that the implementation of a sustainable development strategy in industrial regions is possible by intensifying the process of ecological marketing through the use of new information and communication technologies (ICT) and their innovative tools-methodologies, digital systems, the Internet, cloud technologies, and systems of product design, manufacture and sale- due to accelerated communication links. The authors' approach to the development of the mechanism of creation and functioning of the single information space (field) of the ecological marketing of the industrial region is offered in this work, and also, the classification of modern ICT and their tools, which it is expedient to use in this mechanism, is carried out. Their purpose and the expected results from the introduction of ecological products for market research, the development of ecological technologies for the life cycles of ecological products and, thus, the impact on the acceleration of sustainable development in industrial regions are determined.
\end{abstract}

Keywords: sustainability; industrial region; ecological marketing; information and communication technology; risks of development; digitalization effectiveness; technology assessment

\section{Introduction}

The need for introducing ecological marketing and improving its tools for the sustainable development of large industrial regions is quite relevant, and it is in high demand under modern conditions. After all, we are talking, first, about the socio-economic efficiency of implementing the global doctrine of sustainable development in those regions that have strong industrial potential and, thus, put a significant ecological burden on the health and living standards of socio-territorial communities. Secondly, it is about new globalization challenges associated with the introduction of the digital economy, new information technologies, without which the intensive industrial development and diversification of traditional energy-intensive industries, in line with innovations, becomes 
impossible. The largest industrial region in Poland is the Upper Silesian Industrial District (GOP), and that in Ukraine, Kryvyi Rih. Despite the dominance of coal mining and iron metallurgy in the GOP, which, in the recent PRL (Polish People's Republic) period, concentrated almost $60 \%$ of the employed, other industries such as power engineering, coking, non-ferrous metallurgy, mining, metal structures and vehicles for the mining industry, industrial boilers, the automotive industry, the textile industry, and the glass and food industries did not exceed $8 \%$ in terms of the share of employment (Tkocz 2015).

Kryvyi Rih is a powerful industrial region of Ukraine, on the territory of which there are 137 enterprises belonging to different industries: ferrous metallurgy, machine building, industrial building materials, the chemical industry, printing, woodworking, light industry, the food industry, etc. Among them, there are enterprises of the mining and metallurgical complex of worldwide importance.

According to the results for 2019, Kryvyi Rih occupies one of the leading positions among the cities of Ukraine in terms of the volume of sold industrial products; its share is $7.2 \%$ of the all-Ukrainian indicator, second only to the enterprises of Kyiv (9.3\%). According to the structure of foreign direct investment, about $99 \%$ is accumulated in industrial enterprises, namely, about $57 \%$ is invested in the extractive industry and quarrying, and $42 \%$, in the processing industry. (Oficijnij webportal mista Kriwogo Rogu 2020).

Huge deposits of minerals in these regions have contributed to the fact that they have played and continue to play a crucial role in the development of their countries, as they are significant donors of financial revenues to state budgets from the activities of their industrial enterprises. Moreover, these regions are industrially interconnected, as ore from Kryvyi Rih is exported to industrial plants in Silesia. According to the State Tax Service of Ukraine, exports of ore and iron ore concentrates from Ukraine, in particular, from Kryvyi Rih iron ore enterprises, in 2019, increased by 18.5\% to USD 3.398 billion as compared to in 2018 , and in physical terms, exports of iron ore increased by $8.1 \%$, up to 39.9 million tons. In terms of the recipients of iron ore exports from Kryvyi Rih, Poland (12.7\%) ranks second after China (34.4\%), followed by the Czech Republic (10.3\%) (Gmkcenter 2019).

The high density of industrial enterprises and their activities, of course, on the one hand, has positive features, as they contribute to increasing employment in the population and, consequently, reducing unemployment, but, on the other hand, there are some negative features, namely, the increase in air and water pollution that negatively affects the health of the inhabitants. Therefore, both Silesia and Kryvyi Rih have been implementing programs of sustainable development, the main goal of which is to reduce the industrial load on the environment, lower harmful emissions into the air, preserve the natural landscape and decrease the morbidity of the population caused by industrial factors (Kuzior 2010).

Meanwhile, it should be noted that the effectiveness of the sustainable development strategy in the industrial regions both in Poland and in Ukraine has decreased significantly in recent years, which has negatively affected the ecology of the environment and health of their residents. Polish researchers have drawn attention to this; they have emphasized that "...based on the current strategy, it is difficult to direct the development of the Silesian metropolis to its sustainable development. The strategy requires various changes at many levels-from the ideological base that has little to do with sustainable development through the strategic level to the specific one" (Szwed and Maciejewska 2011).

Ukrainian researchers also pointed out that in the industrial regions of Ukraine, in particular, the Kryvyi Rih region, the situation with the implementation of the doctrine of sustainable development has not reached its active phase, because, "despite municipal and business environmental measures and programs, the environmental situation as the indicator of sustainable development remains dangerous there and needs the search for urgent effective measures aimed at improvement" (Lobanova et al. 2020).

As scientists rightly point out, one of the effective ways is the use of cognitive technologies (Kwilinski and Kuzior 2020). However, their implementation and other modern information and communication technologies require a broader scientific and practical platform, the basis of which is to be able to create environmental marketing. It is well known that ecological marketing is a scientific 
mechanism for diagnosing the state of the ecological market of goods and services, determining the ecological demand and supply for ecological products by industrial enterprises.

Therefore, the aim of the work was to study environmental marketing as a mechanism for creating a market field of eco-products in industrial regions and prove the feasibility of the mechanism of using modern information and communication technologies (ICT), which are innovative tools for implementing the doctrine of sustainable development.

\section{Materials and Methods}

The following theoretical methods were used in the process of the scientific research-analysis and synthesis, formalization, hypothetical-deductive modeling, mental modeling, systematization and generalization—as well as empirical: observations, descriptions, comparisons and experiments. An analysis of the scientific literature was used for gaining an analytical understanding of the content of the concepts of sustainable development, the ecological market, ecological marketing and tools of information and communication technologies. The analysis of statistical indicators and the results of sociological research were used to explain the state of environmental pollution and ecological consciousness of the inhabitants of industrial regions, in particular, Upper Silesia and Kryvyi Rih. With the help of synthesis, formalization, systematization, generalization and a hypothetical-deductive method, the content and structure of the market field of ecological marketing were substantiated, in particular, subjects, eco-demand, eco-offers, market prices, the advertising of eco-products and competition in industrial regions, and information and communication technologies, which should be introduced in it to intensify the strategy of sustainable development. The method of mental modeling is used to build authors' models of the market field of ecological marketing in the industrial region and the information space of ecological marketing in industrial regions in terms of sustainable development and also for the development of methodology for the input of ICT (Information Communication Technologies) of the ecological marketing in industrial regions. Empirical methods were used to verify theoretical positions and conclusions. The state of the environment was monitored directly by the authors regarding the role of the residents of industrial regions. The description and comparison of statistical indicators was used to identify the state of the environment, the eco-market, and the ecological consciousness of the population.

\section{Results and Discussion}

\subsection{Ecological Marketing as a Mechanism for Researching the Market Field of Industrial Regions}

Ecological marketing is the subject of research by economists, ecologists and sociologists, as its subject area is at the intersection of research on human needs, the market structure and demand, the production of ecological goods and services, and the conservation and reproduction of natural resources, i.e., the balanced coexistence of society and the ecosystem. The interest in ecological marketing dates back to the 1960s and 1970s in the 20th century. The ecological crisis has forced a new look at these phenomena. The issue of ecological marketing in scientific studies also appeared gradually in the following years (Fisk 1974; Messmer and Fisk 1975; Henion and Kinnear 1976; Dyllick 1989; Apaiwongse 1993, 1994; Strong 1997). The last decade has brought a large amount of research and scientific studies in this field around the world. Ecological marketing is presented in various contexts and concerns various types of trade (Borges et al. 2009; Lindridge et al. 2013; Gong and Cao 2014; Lockrey 2015; Lee 2007; Páez et al. 2016; Popescu et al. 2017; Jasim and Paramasivan 2017; Esakki 2017; Melovic et al. 2018; Sadykhanova and Rysbayeva 2019; Wang and Wang 2019; Yu et al. 2019; Harini et al. 2020).

According to marketing professionals, its concept is closely linked to the provisions of social marketing, according to which, when making marketing decisions, the company should take into account consumers' wishes, the company's requirements, and the long-term interests of consumers and all of society (Kotler and Armstrong 2012). 
When it comes to ecological marketing, then, of course, the emphasis is shifted to the study of market conditions: (1) the natural environment, (2) the rational offer of minerals, (3) the formation of reasonable needs for the population, and (4) a demand for environmentally friendly and useful goods and services. Thus, it can be argued that ecological marketing is formed on socio-ethical principles and aims at resolving contradictions between industrial production and environmental protection.

According to Ukrainian economists M.V. Malchyk and O.V. Martyniuk, ecological marketing resulted from the integration of two sciences-marketing and environmental management: "Due to the fact that classical marketing lacked its concepts, approaches, measures to restructure enterprises for more modern and environmentally friendly production, and environmental management was not able to clearly regulate the production process, it is more focused on management in the field of environmental protection" (Malchik and Martinyuk 2017).

According to a Polish researcher, J. Brandys, there are three main stages in the formation and development of ecological marketing: the first stage refers to the 1970s, when its appearance was a response to the shortcomings of traditional marketing and associated with its dangers to the natural environment, and its founders focused mainly on analyzing and evaluating the results of marketing operations related to the natural environment and were oriented to the morale of business people; the second stage refers to the 1980s, when the concept of ecological marketing linked social and environmental systems, and environmental issues began to be seen not as a burden on companies but as a market opportunity; the third stage refers to the 1990s, when ecological marketing was already perceived as a strategy and as a concept of management for the entire organization, when environmental issues were among the most important issues for modern companies, and the emphasis was on sustainable development (Brandys 2013).

K. Peattie looks at the evolution of green marketing in terms of three other stages with different marketing implications: (1) ecological marketing, a narrowly focused initiative that concentrated on reducing our dependence on particularly damaging products; (2) environmental marketing, a more broadly based initiative that aimed to reduce environmental damage by tapping into green consumer demand and opportunities for competitive advantage; and (3) sustainable marketing, a more radical approach to markets and marketing that seeks to meet the full environmental costs of production and consumption to create a sustainable economy (Peattie 2004).

There are many definitions of ecological marketing. For example, S. Zaremba-Warnke defines it as "the process of meeting the needs of the consumers and society by means planning and materializing concepts, prices and promotions and dissemination of ideas, goods and services in a way that satisfies the parties to the exchange and is of sustainable nature" (Zaremba-Warnke 2009).

A definition of ecological marketing that is closer to sustainable development is offered by B. Sieńko, who considers it as "a set of integrated measures intended for recognizing and meeting the customers' needs that are more profitable and effective than those offered by competitors and are aimed at satisfying both parties and ensuring sustainable social development" (Sieńko 2000).

Analyzing the attitudes of leading foreign firms and companies to the environmental and, consequently, social consequences of their activities, O.V. Latysheva summarizes five main reasons for the importance of ecological marketing, in particular, the consideration of it as an opportunity to achieve strategic goals; the increase in it due to the moral obligations of economic entities to be more socially responsible to society; the implementation by government agencies of control over the responsibility of enterprises, firms and companies for their activities; the impact of the environmental actions of competing firms on ecological marketing policy; and the change in the attitudes of economic entities to the environment under the influence of cost factors associated with pollution or a scarcity of resources (Latisheva 2007).

Thus, in our opinion, the consideration of ecological marketing, as a process or a set of integrated measures for meeting the environmental needs of society, somewhat narrows its purpose and subject. We believe that ecological marketing should be considered as a scientifically sound mechanism for studying the market field of socially and environmentally oriented industrial production, 
the strategic goal of which is ecological balance, balanced with environmental opportunities and the socio-environmental needs of society for manufacturing environmentally friendly, marketable products with minimum risks to the ecosystem. Ecological marketing can be considered as a system-an ordered set of production relations of economic entities aimed at manufacturing environmentally friendly products, as well as informal and formal rules, principles, norms, methods, values, organizational forms and relationships that ensure the balance (sustainability) of production and ecological systems and reduce the man-made load on the environment (refer to Figure 1).

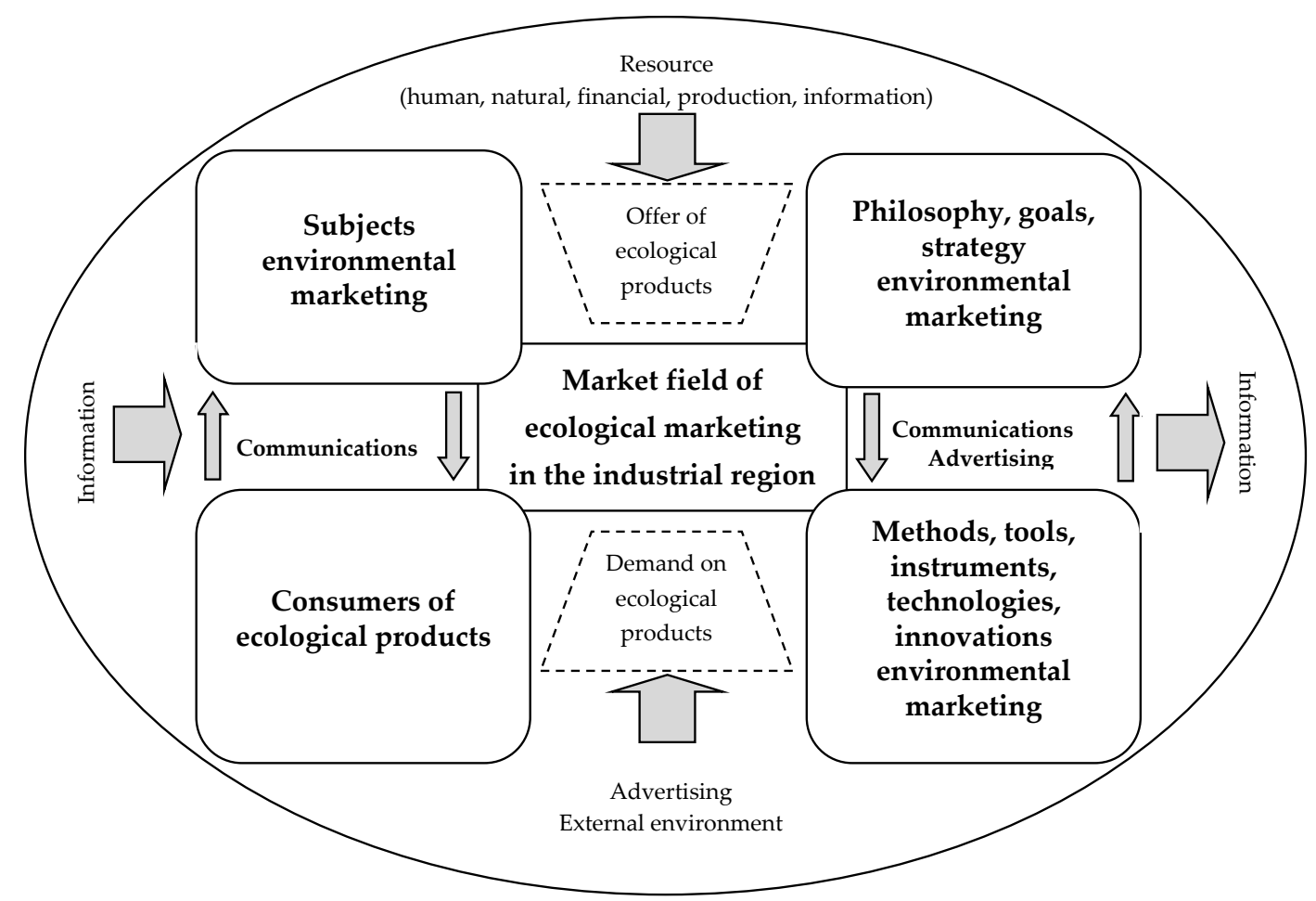

Figure 1. Market field of ecological marketing in the industrial region (the authors' scheme).

Ecological marketing acquires a special significance in industrialized regions, where the load on the ecosystem significantly exceeds the allowable norms. For example, the result of mining and processing activities in Kryvyi Rih was a large-scale disturbance of the Earth's crust and the development of man-made exogenous processes such as landslides, dips, subsidence, the disruption of building foundations, and geotectonic processes-the movement of crust blocks both in the horizontal direction (3-10 mm/year) and in the vertical direction ( $2-5 \mathrm{~mm} / \mathrm{year})$, as well as the pollution of lands, water and air basins with toxic metals of anthropogenic origin, the most dangerous of which are iron, chromium, zinc, mercury, lead, cadmium, etc., to chemical changes that have an extremely negative effect on human health by reducing the natural immunity of people and, hence, the life expectancy (Lobanova and Kalashnikova 2018).

According to sociological research that was conducted systematically in Poland by the DANAE consortium of companies, in Poles' opinions, the biggest environmental problems include air pollution, garbage and climate change. In 2018, compared to the period from 2011 to 2014, many more Poles reported air pollution (an increase from 39\% in 2014 to $62 \%$ in 2018) and climate change (an increase from $22 \%$ to $39 \%$ ). About $50 \%$ of respondents invariably pointed out the problem of waste (Szatanowska et al. 2018).

In the opinion of the inhabitants of the Upper Silesian agglomeration, conventional power plants have always been a serious source of environmental pollution (Adamek and Ziernicka-Wojtaszek 2018).

Thus, ecological marketing is one of the innovative concepts for studying the socio-environmental situation in industrial regions and monitoring the public opinion of communities living in them in order 
to develop socially appropriate strategies for their development, meet the needs for environmental products and form socially responsible business. This is precisely what M. Amir and A. Dhyani draw attention to, stressing that environmental marketing, which is also sometimes called green marketing or sustainable marketing, represents "an opportunity to create innovative products and technologies that meet the needs of customers in the market" and thus receives "huge momentum thanks to the revival of environmental awareness among consumers" (Amir and Dhyani 2019).

It is important to emphasize that "Ecological marketing gives the possibility not only to implement the process of strategic target setting but also shows solutions to many difficulties related do emergence of ecological risk. At that, perceiving of ecological risk by society largely determines the relation of specific enterprise (or type of technology, products, or services) in no lesser way than actual characteristic of influence of production process" (Pozdnyakova et al. 2015).

\subsection{Information and Communication Technologies in Industrial Production Complexes}

The history of ICT development started about 50 years ago. According to N. Kiianivska, the term "information technologies" first appeared in 1964 in an article by John Diebold and the term "information and communication technologies" first appeared in the Computerworld newspaper on 19 September 1977. In Russian-language sources, the concept of ICT was first used in 1983 in the journal "Scientific and Technical Information: Information Processes and Systems", and in Ukraine, it was only used in 1995 in the journal "Problems of Management Theory and Practice" issues No. 1-6 (Kiyanivska 2013).

In a broad sense, ICT (an abbreviation for the English term "information and communication technologies") is a set of various technological devices, tools and resources used to ensure the communication process based on the creation, dissemination, storage and management of information. By these technologies are meant computers, the Internet, radio and television, and telephone (mobile) communication.

The term "information and communication technologies" is often used as a synonym for information technologies (IT), although ICT is a more general term that emphasizes the role of unified technologies and the integration of telecommunications (phone lines and wireless connections), computers, middleware, software, storage and audiovisual systems that allow users to create and obtain access to information, and store, transmit and edit it. In other words, ICT consists of IT, as well as telecommunications, media broadcasts, all types of audio and video processing, transmission, and the network functions of management and monitoring. (Shvachich et al. 2017, p. 5).

As Craig Blurton rightly points out, information and communication technologies are a variety of technological tools and resources used to communicate and to create, disseminate, store and manage information (Blurton 1999).

Polish researcher R. Seweryn emphasizes that ICT includes tools related not only to the retrieval, collection, storage, retention, processing and transmission of information, but also to its reproduction, presentation and elimination. These tools can be classified into four groups: (1) the analysis and synthesis of information (processing, selection and creation), a holistic image of the elements placed in different areas; (2) the impact, creation and use of media messages (including multimedia); (3) social communication through the media; (4) system and data security (Seweryn 2017).

Despite the short history of their development, information and communication technologies have rapidly entered into both everyday and industrial relations. Today, it is impossible to imagine modern industrial production without information and communication technologies, as they have become an integral part of it.

According to Ukrainian economist S. Turlakova, "the complication of smart industry production technologies (Industry 4.0) and the widespread introduction of cyberphysical systems (CPhS) in production processes requires the transition to the use of appropriate information tools, software tools and technical tools". One of the most important factors in the development of "smart" industries is information communication in the enterprise, and information and communication technologies (ICT) become the tool that allows the most effective interaction at all levels of production and management 
(Turlakova 2019, p. 10). Of course, the intensification of communicative relations through the Internet and other information technologies contributes to the increased information competence of staff and, thus, forms the foundation for the development of "smart" industries.

For example, in Ukraine in the metallurgical industry, the following information and communication technologies are actively used (Figure 2):

- Information and reference systems (IRS) that are available on the website of the State Enterprise "Ukrainian Institute of Intellectual Property" (http://www.uipv.org/ua/bases2.html). They are divided into three groups: inventions and utility models, marks for goods and services, and industrial prototypes.

- Patenting and licensing bases: the State Enterprise "Ukrainian Institute of Intellectual Property" (Ukrpatent) has a digital patent library that is divided into sections: patents of Ukraine for inventions, patents of Ukraine for utility models, patents of Ukraine for industrial prototypes, patents of Ukraine for inventions of foreign countries, claims for inventions, international classifications, and regulations.

- Library resources in metallurgy: the Central State Scientific and Technical Library of the Mining and Metallurgical Complex of Ukraine is a state specialized library in the field of metallurgy, mining and related fields; a regional center of the interlibrary service; and the state depository for metallurgy, the only one in the country.

- Systems for supporting production processes, the main tasks of which are to ensure the stability of work and storage of information, administration, the timely modernization and repair of individual elements (technical support), and the adaptation of the capabilities of the operated system to the current business needs of the enterprise (the development of the system).

- Metallurgical systems of B2B, B2C, C2C and B2G types (B2B refers in English to "Business to Business"), referring to a term that defines the type of information and economic interaction classified by the types of interacting entities; in this case, these are legal entities (Shvachich et al. 2017, pp. 70-75).

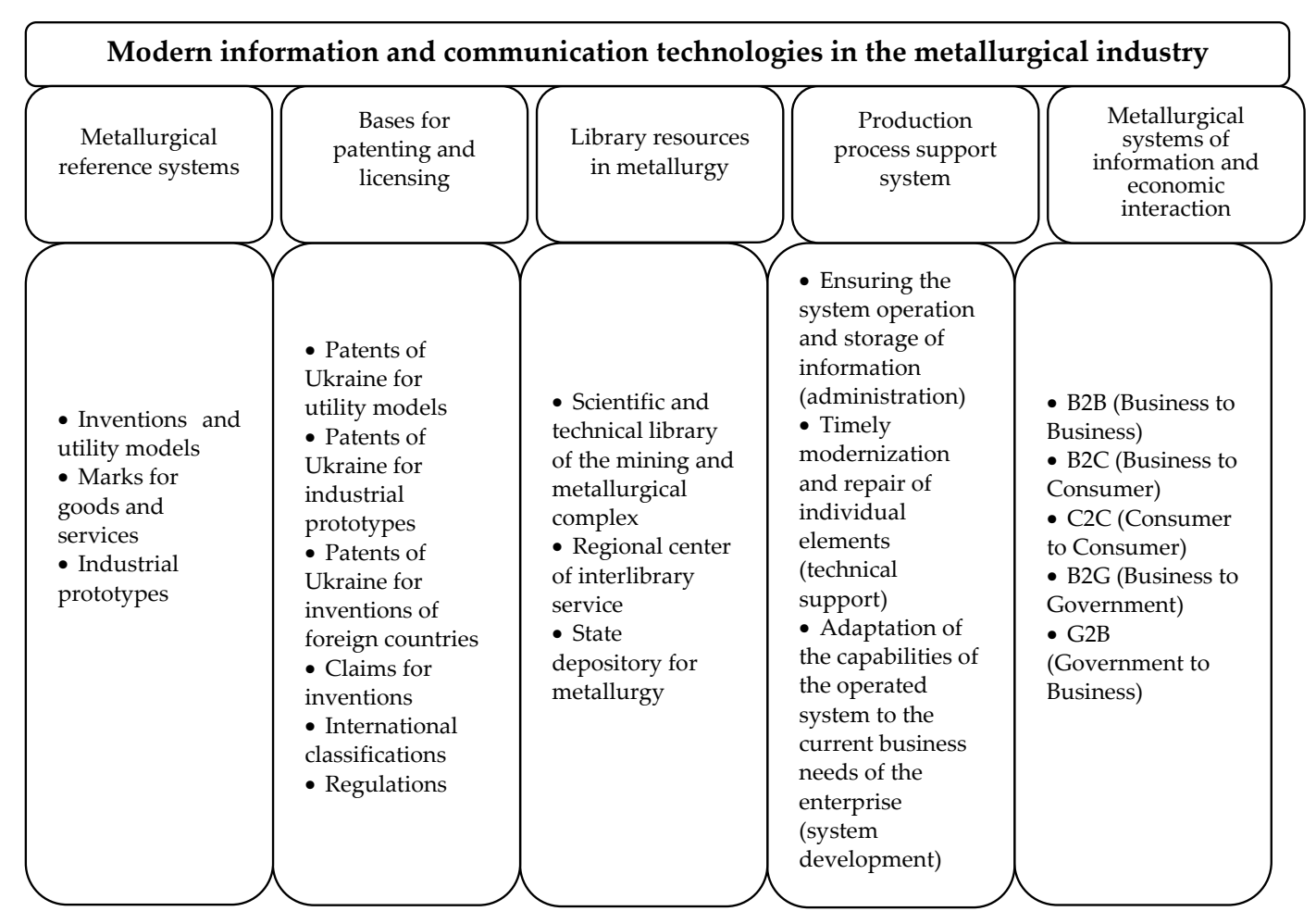

Figure 2. Modern information and communication technologies in steel industry in Ukraine. Source: own study based on the data (Shvachich et al. 2017, pp. 70-75). 
These information and communication technologies are actively used by the personnel of industrial regions, in particular, in the Kryvyi Rih region at metallurgical and mining enterprises.

However, according to S.S. Turlakova, the creation of the unified information space of industrial complexes is a rather difficult task that should be solved with the application of modern methods, tools and management standards related to production planning based on knowledge for Industry 4.0. Such technologies combine various disciplines, including the CPhS, the Industrial Internet of Things, cloud technologies, industrial integration, corporate architecture, business process management, information integration, etc. (Turlakova 2019, p. 10). However, to date, the lack of powerful tools for the development of "smart" production in industrial regions remains a serious problem. The problem, as noted by R. Hba and A. El Manouar, is to "link the ICT strategy with Green IT to provide new managerial and organizational perspectives as well as green market opportunities. In fact, the innovation activity associated with an ecological concern becomes a must to make the difference within a competitive and globalized environmental context" (Hba and Manouar 2018).

One way to solve this problem may be the use of a new environmentally responsible approach to ICT governance in ecological marketing that provides a study of the market field of industrial regions in the implementation of the doctrine of their sustainable development.

\subsection{The Mechanism of ICT Use in the Information Field of Ecological Marketing in the Conditions of Sustainable Development of the Industrial Region}

According to J. Brandys, the concept of ecological marketing in practice is implemented through marketing tools that form the so-called ecological marketing mix that includes the following: the ecological product, its price, environmentally friendly distribution and environmentally friendly promotion (Brandys 2013). It would seem that the process of implementing this mix is simple and usual: the definition of the demand for environmentally friendly products, their production, the determination of the price based on their value, and the formation of a sales system through advertising and meeting consumers' demands. In fact, between the idea of the environmentally friendly manufacturing of products and their sale, there is an extremely complex and multi-component process of ecological marketing that requires coordinated activities of manufacturers, consumers, government agencies, environmental organizations, sellers, buyers, consultants, local governments and, of course, the public.

The mechanism of the introduction of ICT of ecological marketing in the industrial region in the conditions of sustainable development can comprise the following stages.

(A) Definition of Purpose

Since any production activity refers, first of all, to production relations between certain subjects, goals, information, technologies, communication, tools for achieving purposes and corresponding resources are required for its agreement. Therefore, the purpose of introducing information and communication technologies of ecological marketing in the context of the sustainable development of industrial regions is to create conditions for enterprises under which their management and production staff will be interested in modernizing production technologies and seek to rationally use, preserve and restore the natural resource potential of the region.

The main purpose of ecological marketing at the level of a particular subject of industrial relations is to study the market segments of environmentally friendly products and services, and identify the environmentally sound needs of consumers for environmentally friendly goods, a clean environment, and "smart" technologies, in order to focus the production on their satisfaction.

(B) Research on the Market of Ecological Products in the Industrial Region, Which Consists of the Following Marketing Operations:

- The study of the demand for ecological products;

- The segmentation of the market of ecological products according to the solvency of buyers;

- Planning the range of ecological products, pricing, advertising and promoting the sales of environmental products; 
- Activities for the organization of the environmentally friendly turnover of commodities, warehousing, transportation and customer service;

- The environmental orientation of the products, as well as the entire cycle of their production to consumption, from the extraction of raw materials to their disposal;

- Increasing responsibility for solving environmental problems at all levels of the organizational structure of the enterprise, taking into account the system of environmental performance evaluation criteria;

- The improvement of the system for the encouragement of the initiative of the ecological improvement of production and consumption;

- The creation of a positive image of the company (Bagorka 2019).

(C) Creation in Industrial Regions of a Single Information Space (Field) of Ecological Marketing on the Basis of "Cloud" Technologies (Volgin et al. 2012)

In the single information space (field) of the ecological marketing of the industrial region, actualized information and communication technologies among experts of various profiles, manufacturers, consumers at the stages of researching the market and its structure, and the clarification of the demand and pricing for environmentally friendly products form the supply structure-as well as the design, production, marketing and other stages of the life cycle of production and promotion to the consumer (buyer) of eco-products and eco-technologies-and define expedient and dynamic communicative decisions for the realization of integration tasks under conditions of sustainable development (refer to Figure 3).

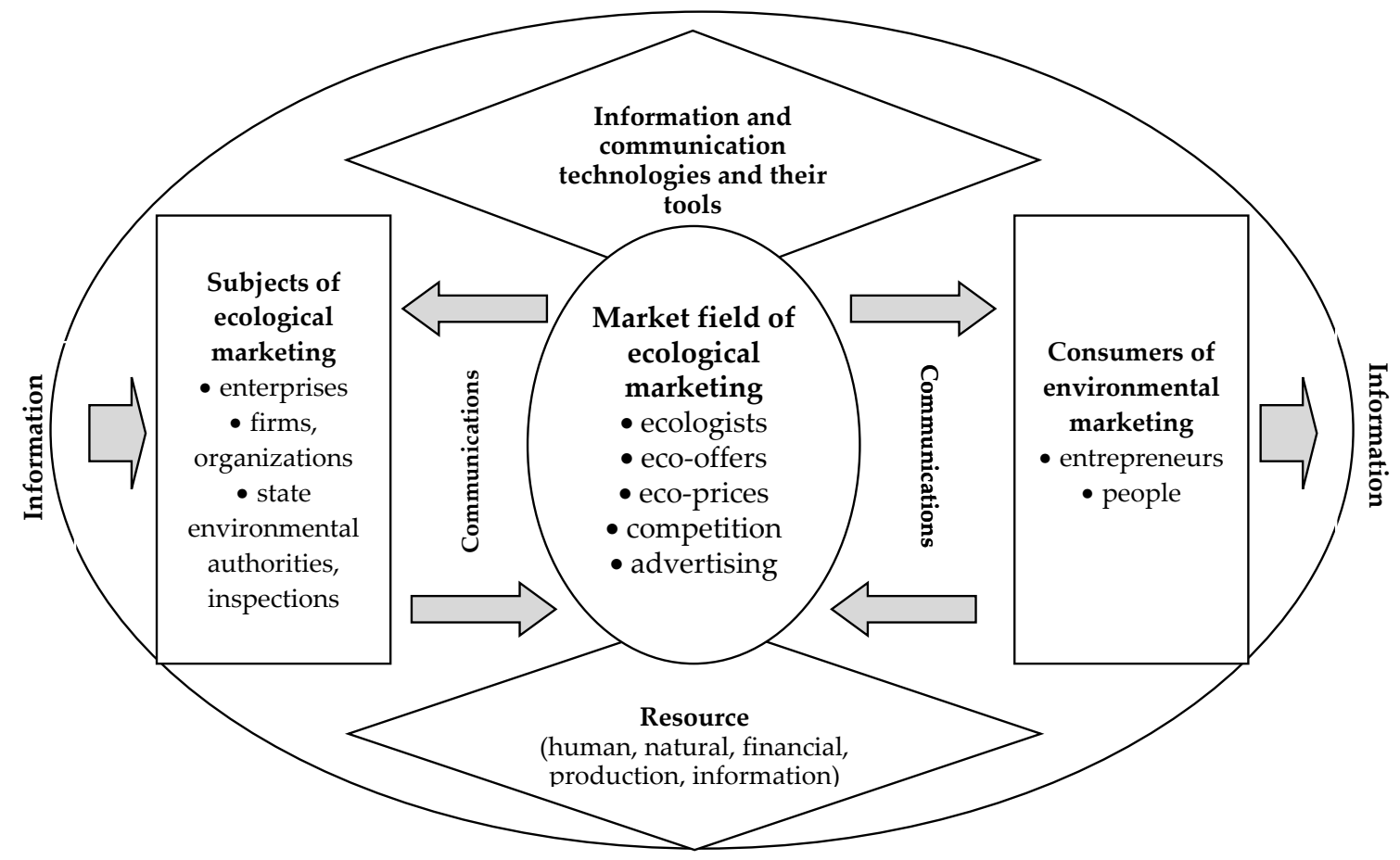

Figure 3. Information space (field) of ecological marketing in industrial regions under conditions of sustainable development (the authors' scheme).

(D) Selection and Implementation of ICT and Their Tools in the Information Field of Environmental Marketing to Optimize Market and Production Activities of Enterprises

According to E. Wojnicka-Sycz, ICT have special potential for stimulating business networks and contributing to knowledge exchange. Web portals are created by associations interested in various issues that can significantly increase the innovativeness of small and medium enterprises under Web 2.0 conditions (Wojnicka-Sycz 2013). 
The most effective tool of ICT for ecological marketing in the industrial region under conditions of sustainable development can be, first of all, CALS technology (Continuous Acquisition and Life Cycle Support); it is a strategy for a systematic increase in the efficiency, productivity and profitability of processes of economic activities of the corporation due to the introduction of modern methods of information interaction of the participants in the product's life cycle. The development of CALS technologies promotes the electronic integration of distribution lines into the management and service processes-from the creation of the product design to its disposal. The information base of CALS tools is based on the use of international standards, common locations for data storage, created machine constructions, tested software and hardware resources (CALS-tehnologiy I Opredelenie Opisanie Harakteristiki).

This technology was first used in the 1980s in the US defense industry for the purpose of Computer Aided Logistic Support. Later, it spread to other areas of the economy and to the entire life cycle of the product (from marketing to disposal). The implementation of CALS technologies in practical terms involves the organization of the unified information space (integrated information environment) that combines automated systems intended both for the effective solution of engineering problems and for the planning and management of production and the resources of the enterprise.

According to experts, the use of CALS technologies should be complemented by the use of computer-aided design (CAD)/computer-aided manufacturing (CAM)/computer-aided engineering (CAE) systems within different departments that allows one to formalize and identify the users' interactions in the unified information space of a separate enterprise and industrial region. CAD systems (computer-aided design systems) are intended for solving designing problems and the preparation of design documentation (these systems are more commonly called automated design engineering systems). As a rule, modern CAD systems include modules for simulating the three-dimensional structure (part) and preparation of drawings and text design documentation (specifications, data, etc.). Leading three-dimensional CAD systems allow implementing the idea of a through cycle of the preparation and production of complex industrial products.

In turn, $C A M$ systems (computer-aided manufacturing systems) are intended for designing the processing of products on machines with Computer-Numeric Control $(\mathrm{CNC})$ and the issuance of programs for these machines (milling machines, drilling machines, erosion machines, punching machines, turning machines, grinding machines, etc.). CAM systems are also called systems of technological preparation of production. Currently, they are almost the only way to manufacture parts with complex profiles and reduce the cycles of their production. CAM systems use a three-dimensional model of the part created in the CAD system. CAE systems (computer-aided engineering systems) refer to a large class of systems, each of which allows solving a specific calculation problem (group of tasks), ranging from strength calculations and the analysis and simulation of thermal processes to calculations of hydraulic systems and machines, and calculations of casting processes. CAE systems also use a three-dimensional model of the product created in the CAD system. CAE systems are also called systems of engineering analysis (Glinskih 2002).

$\mathrm{CAD} / \mathrm{CAM} / \mathrm{CAE}$ systems are industrial technologies that are expedient to use in material production, especially when it comes to the manufacture of complex science-intensive products, such as ships, aircraft, tanks and various types of industrial equipment. In recent years, CAD/CAM/CAE systems have gone down a path from relatively simple drawing applications to integrated software packages that provide unified support for the entire cycle of product development-from sketch design to the technological preparation of production, testing and maintenance. Modern CAD/CAM/CAE systems not only allow reducing the time required for the introduction of new products but also significantly affect the production technology, allowing an increase in the quality and reliability of products (thereby increasing their competitiveness). Therefore, the production of eco-products and eco-technologies is almost impossible without the use of tools of CAD/CAM/CAE systems. 
The IDEF0 methodology of functional simulation, IDEF1X methodology of information simulation and cloud-computing technology can also be effective ICT tools for ecological marketing (Volgin et al. 2012).

The IDEF0 methodology of functional simulation (Integrated Definition for Function Modeling) means the definition of integration for process models, a publicly available domain methodology that is used to simulate enterprises and their processes for simplifying their understanding and ensuring their improvement (Sozdanie shemy IDEF0).

The IDEF1X methodology of information simulation is an extension of the IDEF1 standard and is intended for describing data (information). It is based on the language of semantic simulation, based on the concept of "entity-connection", which allows determining the data and the relationship between them. The methodology is used for creating the information model of the subject area by identifying its entities and the relationships between them. Most often, this methodology is used to describe data for the further automation of their processing with the use of database management systems. Thus, we can say that the data models in the IDEF1X notation are used to create databases. The main elements of the IDEF1X model are entities, attributes and relationships (Metodologiya IDEF1X).

Cloud computing is the development of the process of industrialization in the field of IT, and it contributes to the standardization and optimization of the computing and information technology infrastructure, as well as the dynamic redistribution of resources. Cloud computing does not imply that the user knows something about the architecture and other features of the computing tools he/she uses.

Cloud computing is a paradigm of distributed large-scale computing, where a set of abstract, virtualized, dynamically scalable, remotely controlled machines, memory mechanisms, platforms and services are provided on the request of the remote user via the Internet (Semenov 2009).

An important tool of ICT ecological marketing is SCADA systems (Supervisory Control and Data Acquisition)—software and hardware systems for data collection and control that allow one, based on mathematical models, to determine, install and maintain in the equipment of industrial enterprises environmentally safe and cost-effective modes of operation, taking into account relevant restrictions (Dmitriev and Gandzha 2013).

As S. Turlakova emphasizes in her monograph "Information and Communication Technologies for the Development of "Smart" Industries: Scientific-Analytical Report", a structural approach and, in particular, the methodology of the construction of Structured Analysis and Design Techniques (SADT) models allows illustrating the functions of the system and the relationships between the data and allows one to most fully consider the information and communication links of the simulated systems. Among the formal means for modeling the complex of control systems within the structural approach, the following are widely used:

- SADT methodology (Structured Analysis and Design Techniques)—a technology that focuses on a comprehensive view of the structure of the system, including information flows and communication links.

- DFD (Data Flow Diagram) - models depicting the transfer of data between operations and the characteristics of the information side of the business processes of the system.

- ERD (Entity Relationship Diagram) - models of the "entity-relationship" type that allow representing the conceptual schemes of the subject area and that are used in the design of databases. ERD diagrams are intended for the graphical representation of data models of the software system and offer a set of standard notations for determining the individual components of the conceptual data model and the set of relationships between them.

- STDs (State Transition Diagrams) - diagrams of transition states that are intended for simulating those aspects of business processes that depend on time or the response to the event. The simulated process at any given time is exactly in one state of their finite set (Turlakova 2019, p. 16).

According to the Polish researcher E. Wojnicka-Sycz, effective ICT tools that should be used for organizational innovations in the management system are as follows: 
- Lean Management/Manufacturing-economical (lean) production, the bases of which are "timeliness" and "autonomy". It is based on the concept of the constant flow and timely "extraction" of production due to demand, rapid changes in tools and the integration of logistics.

- Business process re-engineering (BPR) is a way of analyzing and processing business processes within and between enterprises.

- Six Sigma-a data-driven methodology used to increase productivity by limiting variability. This tool requires a deep understanding of products and processes and is fully guided by the customer's expectations. This is a methodology that exhibits 3-4 defects per million possibilities.

- Knowledge management-knowledge-based engineering (KBE), which deals with the computerization of processes related to the industrial design and routine design of the product. Knowledge-based engineering programs are intended to capture and codify the knowledge of employees across the organization (Wojnicka-Sycz 2013).

We believe that these ICT tools can and should be widely used in the functioning of the information market field of environmental marketing in the industrial region to implement the concept of sustainable development, which is based on the creation of a single information space (field) of the industrial region.

(E) Diagnosis of the Effectiveness of the Use of ICT in Environmental Marketing of the Industrial Region, Monitoring Public Opinion on Meeting the Environmental Needs of the Population of the Region, Conducting Marketing Research in the Market of Environmental Products

This is an important stage of the mechanism of the introduction and implementation of ICT in the ecological marketing of the industrial region, which reveals the effectiveness and feasibility of various ICT and their tools for the formation and functioning of the ecological space in the industrial region. Decisions are made, as noted by S. Samal, on "environmentally sustainable supply chains and their interaction in green industrial branding, discussion of potential ways of science development" (Samal 2019), the modernization of enterprises, the introduction of innovations, personnel decisions, the branching of international relations and the implementation of socially responsible activities.

Of course, the presented mechanism for the introduction and realization of ICT in a single information field of the ecological marketing of industrial regions requires appropriate intellectual, social, informational and financial resources. However, there is no alternative in the face of globalization challenges and rapid depletion and pollution.

\subsection{Experience in Introducing Information and Communication Technologies in the Industrial Regions of Poland and Ukraine}

The process of introducing ICT in the industrial regions of Poland and Ukraine began practically with the development of the Internet. Large industrial enterprises under the conditions of the formation of the information society and globalization challenges were forced to introduce the latest technologies, which, by accelerating communication processes, contribute to the intensification of production processes, dynamic changes in design and technological systems, the introduction of environmental technologies and the production of environmental products and services.

According to surveys of NGOs (non-government organizations) in Poland, large companies (76.9\%) use ICT more often than small companies (40\%) and medium companies (57.4\%). This means that especially small companies face barriers related to the introduction of ICT tools, which reduces opportunities for increasing their innovativeness and competitiveness in the market (Wojnicka-Sycz 2013). The need for the more active use of ICT tools in the mining industry was discussed in the sessions of the XXIX School of Underground Mining in Krakow (20.02.2020), where scientists from universities and mining institutes (AGH, GIG, Silesian Polytechnic University, University of Technology) and practicing specialists from Polish mines and mining companies attended. During the session, issues related to mechanized wall cladding were discussed: from the production of new coverings, through their modernization, to reconstruction. The ZRP (Zememowit Ruch Piast) also actively develops the design of devices, their own projects taking into account the current and future needs of the company, which include high safety standards, the improvement of production processes, 
their standardization and robotics. Particular attention was paid to the use of modern methods of measurement in mining, such as fortogrammetry, laser scanning or radar interferometry (InSAR), as well as the computer simulation of the mountain surface. D. Bigun, a Supervisor of Geodetic and Geological Mining at Piast-Zememowit Ruch Piast in the Polish Mining Group, presented the possibilities of using the Map-Draw system for the three-dimensional modeling of selected elements of the digital map (PolskaGrupaGórnicza 2020).

In Ukraine, the process of ICT implementation is also underway, although it is not as fast as in Poland. For example, the "smart" technology "Mobile Traffic Light" was introduced at Metallurgical Works "Zaporizhstal" for the operational monitoring of production processes: in the latten shop, in pilot mode, 2000 sensors that allow reading 130,000 parameters of equipment operation were installed. The program allows one to quickly make decisions about the timely implementation of the required repair works: it takes into account the percentage of wear, the frequency of replacement of parts, the service life, the defect development rate, etc., and it provides for the collection and entry of data on the state of equipment in the unified electronic database of the equipment in all workshops. Approximately the same system has been used at the Interpipe Steel plant since 2016; it is the SmartEAM module for the maintenance and repair of equipment (developed by the Ukrainian company "IT-Enterprise"), which includes all the information about the main equipment of the plant, including drawings and repair maps for each assembly. Currently, the Interpipe Steel plant is implementing another system - the Smart Factory system - a project for the end-to-end tracking and planning of production. The system is based on industrial Internet of Things (IoT) technology_information about each product (for example, the smelting number, steel grade, order number, etc.) is stored in a single database. The Interpipe plant is testing this system in the production of pipes, but it may be adapted to any enterprise. Probably, in the near future, such modules will appear at other metallurgical plants as well (Lobanova et al. 2020).

Of course, these ICT that have been already introduced in industrial regions for meeting the environmental demand for ecological products and services do not address the main goals of the concept of sustainable development. Meanwhile, the formation of ecological marketing using ICT tools will significantly accelerate the implementation of the main tasks facing Polish and Ukrainian producers and scientists-the creation of energy-intensive and environmentally friendly technologies, goods and services, the production of which does not harm the environment, significantly improves communication between the residents of industrial regions, and improves their standard of living. It also opens up new opportunities for even more advanced and perhaps more effective organic marketing. We are talking about cognitive technologies and artificial intelligence (Kuzior et al. 2019; Kwilinski et al. 2019; Tkachenko et al. 2019).

However the use of instruments of IKT must comply with the standards for part quality control (ISO 9001), the protection of the environment (ISO 14001), health and safety at work (ISO 45001), the security of information (ISO/IEC 27001), etc. The observance of standards is the fundamental basis for the realization of ecological marketing in industrial regions that assists the effective updating of functional constituents, in particular, informatively communicative technologies (Normy ISO).

\section{Discussion}

In the area of sustainable development, information and digital technologies are gaining ground, without which it is difficult to imagine modern technological processes in production, as they are integral components of industrial relations between their subjects and other agents of the economy. The novelty of this scientific work is the development of a mechanism for the formation of a single information space (field) of environmental marketing in the industrial region, which is based on the latest ICT and their tools.

The mechanism of introduction of ICT of ecological marketing in the industrial region in the conditions of sustainable development can comprise the following stages: (A) the definition of the purpose; (B) a study of the market for organic products in the industrial region, which consists of 
the following marketing operations; $(\mathrm{C})$ the creation in industrial regions of a single information space (field) of ecological marketing on the basis of "cloud" technologies; (D) the selection and implementation of ICT and their tools in the information field of environmental marketing to optimize the marketing and production activities of enterprises.

ICT and their tools are a set of various information resources used to study the market of organic products, its subjects, the structure, environmental demand, supply, advertising and branding, as well as to establish and improve communication links between the producers, suppliers and consumers of organic products. Table 1 presents modern ICT, which, in our opinion, it is advisable to introduce in environmental marketing in industrial regions.

Table 1. ICT tools of ecological marketing, their purpose and expected result.

\begin{tabular}{|c|c|c|}
\hline $\begin{array}{l}\text { ICT Tools in Ecological } \\
\text { Marketing }\end{array}$ & Purpose & Expected Result \\
\hline $\begin{array}{l}\text { IDS (information and reference } \\
\text { systems) }\end{array}$ & $\begin{array}{l}\text { Obtaining the necessary information } \\
\text { about utility models; signs for goods } \\
\text { and services; industrial samples of } \\
\text { ecological products }\end{array}$ & $\begin{array}{l}\text { Opportunity to take into account the } \\
\text { demand in the environmental market } \\
\text { and produce new environmental } \\
\text { brands }\end{array}$ \\
\hline Patents and licensing bases & $\begin{array}{l}\text { Patenting of ecological inventions and } \\
\text { their legal support }\end{array}$ & $\begin{array}{l}\text { Guarantee of competitiveness of new } \\
\text { goods and services in the ecological } \\
\text { market }\end{array}$ \\
\hline Library resources in metallurgy & $\begin{array}{l}\text { Accumulation and storage of } \\
\text { information sources and scientific } \\
\text { achievements in the field of industry } \\
\text { and ecology }\end{array}$ & $\begin{array}{l}\text { Development of research in the field } \\
\text { of environmental marketing in } \\
\text { industrial regions }\end{array}$ \\
\hline $\begin{array}{l}\text { Production process support } \\
\text { systems }\end{array}$ & $\begin{array}{l}\text { Ensuring the stability of work and } \\
\text { storage of information }\end{array}$ & $\begin{array}{l}\text { Effective administration, timely } \\
\text { modernization and repair of separate } \\
\text { elements, adaptation of possibilities of } \\
\text { the operated system to current needs } \\
\text { of business of the enterprise }\end{array}$ \\
\hline $\begin{array}{l}\text { Metallurgical systems such as B2B, } \\
\text { B2C, C2C and B2G }\end{array}$ & $\begin{array}{l}\text { Determining the type of information } \\
\text { and economic interaction, classified by } \\
\text { types of interacting entities }\end{array}$ & $\begin{array}{l}\text { Optimizing the relationship between } \\
\text { business, customers and government }\end{array}$ \\
\hline $\begin{array}{l}\text { CALS technology (Continuous } \\
\text { Acquisition } \\
\text { and Life Cycle Support), }\end{array}$ & $\begin{array}{l}\text { Electronic integration of distribution } \\
\text { lines into management and service } \\
\text { processes, from product design to } \\
\text { disposal }\end{array}$ & $\begin{array}{l}\text { Systematic increase in efficiency, } \\
\text { productivity and profitability of } \\
\text { processes of economic activity of } \\
\text { corporation }\end{array}$ \\
\hline $\begin{array}{l}\text { CAD systems (computer-aided } \\
\text { design) }\end{array}$ & $\begin{array}{l}\text { Implementation of the idea of a through } \\
\text { cycle of preparation and production of } \\
\text { complex industrial products }\end{array}$ & $\begin{array}{l}\text { Simulation of the three-dimensional } \\
\text { structure (part) and preparation of } \\
\text { drawings and text, preparation of } \\
\text { documentation (specifications, data, } \\
\text { etc.) }\end{array}$ \\
\hline $\begin{array}{l}\text { CAM systems (computer-aided } \\
\text { manufacturing) }\end{array}$ & $\begin{array}{l}\text { Computer support for the production of } \\
\text { new environmental products }\end{array}$ & $\begin{array}{l}\text { Design of processing of products on } \\
\text { machines with numerical program } \\
\text { control and reduction of a cycle of } \\
\text { their production. }\end{array}$ \\
\hline $\begin{array}{l}\text { CAE systems (computer-aided } \\
\text { engineering) }\end{array}$ & Implementation of engineering analysis & $\begin{array}{l}\text { Solving computational problems, } \\
\text { ranging from strength calculations, } \\
\text { analysis and modeling of thermal } \\
\text { processes to calculations of hydraulic } \\
\text { systems and machines, } \\
\text { and calculations of casting processes. }\end{array}$ \\
\hline $\begin{array}{l}\text { IDEF0 (Integrated Definition for } \\
\text { Function Modeling }\end{array}$ & $\begin{array}{l}\text { Functional modeling of activity, } \\
\text { structure of ecological market and } \\
\text { release of new ecological production }\end{array}$ & $\begin{array}{l}\text { Improving modeling of enterprises } \\
\text { and their processes }\end{array}$ \\
\hline $\begin{array}{l}\text { IDEF1X (Integrated Definition for } \\
\text { Information Modeling) }\end{array}$ & $\begin{array}{l}\text { Creation of databases of industrial } \\
\text { enterprises for development of } \\
\text { strategies of ecological marketing }\end{array}$ & $\begin{array}{l}\text { Information modeling of activity, } \\
\text { structure of ecological market and } \\
\text { release of new ecological production }\end{array}$ \\
\hline
\end{tabular}


Table 1. Cont.

\begin{tabular}{|c|c|c|}
\hline $\begin{array}{l}\text { ICT Tools in Ecological } \\
\text { Marketing }\end{array}$ & Purpose & Expected Result \\
\hline Technology Cloud computing & $\begin{array}{l}\text { Standardization and optimization of } \\
\text { computing and information technology } \\
\text { infrastructure }\end{array}$ & Dynamic redistribution of resources \\
\hline $\begin{array}{l}\text { SCADA systems (Supervisory } \\
\text { Control and Data Acquisition) }\end{array}$ & $\begin{array}{l}\text { Data collection and dispatch control } \\
\text { over the activities of all production } \\
\text { processes }\end{array}$ & $\begin{array}{l}\text { Installation and support in the } \\
\text { equipment of the industrial } \\
\text { enterprises of ecologically safe and } \\
\text { economically effective operating } \\
\text { modes taking into account the } \\
\text { corresponding restrictions }\end{array}$ \\
\hline $\begin{array}{l}\text { SADT (Structured Analysis and } \\
\text { Design Techniques) }\end{array}$ & $\begin{array}{l}\text { Comprehensive representation of the } \\
\text { structure of the system, including } \\
\text { information flows and communication } \\
\text { links both in the enterprise and in the } \\
\text { environmental market }\end{array}$ & $\begin{array}{l}\text { Optimization of production and } \\
\text { market relations between producers } \\
\text { and consumers of ecological products }\end{array}$ \\
\hline DFD (Data Flow Diagram) & $\begin{array}{l}\text { Data transfer between operations and } \\
\text { characteristics of the information side of } \\
\text { the business processes of the system }\end{array}$ & $\begin{array}{l}\text { Improvement of production processes } \\
\text { and promotion of ecological products } \\
\text { to the consumer }\end{array}$ \\
\hline $\begin{array}{l}\text { ERD (Entity Relationship } \\
\text { Diagram) }\end{array}$ & $\begin{array}{l}\text { Presentation of conceptual schemes of } \\
\text { the problem area in production or in the } \\
\text { market }\end{array}$ & $\begin{array}{l}\text { Graphical representation of any } \\
\text { problem through the "essence } \\
\text { connection" for its effective solution }\end{array}$ \\
\hline STD (State Transition Diagrams) & $\begin{array}{l}\text { Modeling those aspects of business } \\
\text { processes that depend on time or } \\
\text { reaction to an event in the } \\
\text { environmental market }\end{array}$ & $\begin{array}{l}\text { Dynamization of production processes } \\
\text { in response to consumer demand for } \\
\text { environmental products }\end{array}$ \\
\hline Lean Management/Manufacturing & $\begin{array}{l}\text { Economical (lean) production, based on } \\
\text { "timeliness" and "autonomy" }\end{array}$ & $\begin{array}{l}\text { Ensuring a constant flow and timely } \\
\text { "extraction" of production through } \\
\text { demand, rapid tool changes and } \\
\text { logistics integration }\end{array}$ \\
\hline $\begin{array}{l}\text { BPR (business process } \\
\text { reengineering) }\end{array}$ & $\begin{array}{l}\text { Analysis and processing of business } \\
\text { processes within enterprises and } \\
\text { between them }\end{array}$ & $\begin{array}{l}\text { Increasing the productivity of } \\
\text { ecological products }\end{array}$ \\
\hline Six Sigma & $\begin{array}{l}\text { Increasing the productivity of ecological } \\
\text { products by limiting variability }\end{array}$ & $\begin{array}{l}\text { Expansion of production capabilities } \\
\text { of the enterprise }\end{array}$ \\
\hline KBE (knowledge management) & $\begin{array}{l}\text { Computerization of processes related to } \\
\text { industrial design and routine product } \\
\text { design }\end{array}$ & $\begin{array}{l}\text { Capture and codify the knowledge of } \\
\text { employees from all over the } \\
\text { organization }\end{array}$ \\
\hline
\end{tabular}

Source: authors' elaboration.

The work considers modern ICT and their tools that should be used in the process of ecological marketing in the information market space of industrial regions (Table 1).

There are many indicators of the effectiveness of environmental marketing. For example, standard indicators include the growth in the consumers of ecological products, market share and sales volume (Harini et al. 2020); the impact of production processes on the formation of a healthy environment and society, and the number of environmentally responsible consumers (Melovic et al. 2018); the state of the environment, personalized goods, their prices and experience (Wang and Wang 2019, pp. 3594-95); and others.

Scientists mark justly that for effective ecological marketing, it is necessary to put right and support mass communications with different task forces of consumers, to form the culture of the consumption and social responsibility of a business before society (Lindridge et al. 2013).

In the context of sustainable development, the emphasis in environmental marketing indicators changes from economic to social and ethical. Therefore, there is a need for the formation of new integrated indicators as the embodiment of new environmental thinking.

In our opinion, the leadership and competitiveness of the enterprise in the market of ecological goods and services can be integral indicators of the efficiency of application of the considered ICT tools 
in the ecological marketing of industrial regions. Achieving leadership is possible through the introduction of the principles of sustainable development, production of new eco-products, rational use of natural resources, balanced personnel policy and social responsibility to society. Competitiveness is a component of leadership, which is achieved solely on the basis of the introduction of new technologies and reformatting the environmental consciousness of entrepreneurs. It is considered in the work of tooling ICTs, and their tools help to accelerate the process of finding the necessary information for industrial enterprises; research on the market of ecological products, including the eco-demand, eco-supply, eco-price, competition, and promotion of eco-products and eco-services to the consumer; and the development of ecological technologies for eco-products' life cycle and, thus, the acceleration of industrial integration, the formation of corporate architectures, and improvement of business process management in industrial regions.

Of course, ICT tools are actively used in the industrial regions of many countries around the world, but the slow pace of implementation of the doctrine of sustainable development indicates a lack of attention to their integrated use in environmental marketing. Therefore, it seems appropriate, especially in developing countries, to encourage the widespread use and application of new scientific approaches to the formation of environmental markets through the introduction of various ICT tools.

\section{Conclusions}

In the current conditions of dynamic economic development, the global trend is the doctrine of sustainable development that has been implemented over the past 20 years in many countries, including Poland and Ukraine.

Meanwhile, according to experts, in recent years, there has been a slowdown in the main tasks of sustainable development or the pace of their solution is too slow. This problem, in our opinion, may be solved by improving the system of ecological marketing based on information and communication systems and their tools.

In scientific understanding clarified by us, ecological marketing should be considered as a scientifically sound mechanism for studying the market field of socially and ecologically oriented industrial production, the strategic goal of which is an ecological balance that is sustainable regarding natural resources and the socio-ecological needs of society in the process of manufacturing environmentally friendly products and eco-technologies with minimal risks to the ecosystem. As a system, ecological marketing is an orderly set of production relations of the subjects of economic activities aimed at clarifying the structure of the eco-market and production of environmentally friendly products and that is subject to legal and ethical rules, principles, norms, values, organizational forms and relationships that ensure the balance (sustainability) of production and environmental systems and reduce the man-made burden on the environment.

The modern field of ICT, which is saturated with a variety of information products, allows the instrumental improvement of environmental marketing in the industrial regions of Poland and Ukraine, and thus increases the competitiveness of industrial enterprises in the global market of environmental products. As noted by Sh. Huang, the competitiveness of the environmental industry will directly affect the profitability and efficiency of the enterprise in a rapidly changing competitive environment (Huang 2018).

Promising areas for further research in the field of ecological marketing and sustainable development of industrial regions are as follows: the search for new ICT to improve a differentiated approach to pricing the products of enterprises, taking into account the environmental costs of reducing wastes and their disposal, removal and recycling; the organization of effective systems for reducing the environmental risks associated with the irrational use of natural resources and disturbance of the balance of eco-systems and social systems; and the use of new tools of cognitive technologies and artificial intelligence for ecological, economic and social purposes, in accordance with the assumptions of the concept of sustainable development. 
Author Contributions: Conceptualization, A.K.; Methodology, A.L.; Resources, A.K. and A.L.; Writing—original draft preparation, A.L.; Writing-review \& editing, A.K. All authors have read and agreed to the published version of the manuscript.

Funding: Research funded from Department of Applied Social Sciences of the Faculty of Organization and Management of the Silesian University of Technology directional research for the year 2020.

Conflicts of Interest: The authors declare no conflict of interest.

\section{References}

Adamek, Adam, and Agnieszka Ziernicka-Wojtaszek. 2018. Świadomość ekologiczna mieszkańców aglomeracji górnośląskiej. Rocznik Ochrona Środowiska 18: 1653. Available online: https://ros.edu.pl/images/roczniki/2018/ 097_ROS_V20_R2018.pdf (accessed on 2 October 2020).

Amir, Mohd, and Atul Dhyani. 2019. Measuring consumers' perception and determinants of green purchase. International Journal of Advanced Science and Technology 28: 250-69.

Apaiwongse, Tom S. 1993. Market responses to EPA policies. Industrial Marketing Management 22: 319-30. [CrossRef]

Apaiwongse, Tom S. 1994. The Influence of Green Policies on a Dual Marketing Center: An Ecological Marketing Approach. Journal of Business \& Industrial Marketing 9: 41-50. [CrossRef]

Bagorka, Maria. 2019. Koncepciya ekologichnogo marketingu v marketingovij strategiyi stalogo rozvitku virobnictva agrarnih pidpriyemstv. Intelekt XXI 3: 23-28. Available online: http://nbuv.gov.ua/UJRN/int_ XXI_2019_3_5 (accessed on 24 May 2020).

Blurton, Craig. 1999. New Directions in Education. Communication, Information and Informatics Sector/World Communication and Information Report 1999-2000. Paris: UNESCO, Available online: http://www.unesco.org/ webworld/wcir/en/pdf_report/chap2.pdf (accessed on 24 May 2020).

Borges, L., M. Sosa, I. Huerta, J. Pérez, and E. Segovia. 2009. Attitude toward ecological marketing like management philosophy in the shrimp industry of Zulia state. Revista de la Facultad de Agronomia 26: 266-92.

Brandys, Joanna. 2013. Environmental marketing_Assumptions and prospects. Zeszyt Naukowy.pl/Wyższa Szkoła Zarzązania i Bankowości w Krakowie 27: 53-65. Available online: http://bazekon.icm.edu.pl/bazekon/element/ bwmeta1.element.ekon-element-000171350237 (accessed on 24 May 2020).

Dmitriev, Viacheslav, and Taras Gandzha. 2013. Princip formirovaniya mnogourovnevyh kompyuternyh modelej SCADA-sistem dlya upravleniya slozhnymi tehnologicheskimi obektami. Modelirovanie System 2: 24-35.

Dyllick, Thomas. 1989. Ecological marketing strategy for Toni yogurts in Switzerland. Journal of Business Ethics 8: 657-62. [CrossRef]

Esakki, Thangasamy. 2017. Eco-friendly culpabilities of modern corporates on ecological marketing: An overview. IGI Global, 182-200. [CrossRef]

Fisk, George. 1974. Marketing and the Ecological Crisis. New York: Harper \& Row.

Glinskih, Aleksandr. 2002. Obshiesvedeniya o CAD/CAM/CAE-sistemah. ИнфОрМ 1: 117. Available online: http://old.ci.ru/inform01_02/p_22-23.htm (accessed on 24 May 2020).

Gmkcenter. 2019. Eksport rudi z ukraïni u 2019 rocizris na 18,5\%. Available online: https://gmk.center/ua/news/ eksport-rudi-z-ukraini-u-2019-roci-zris-na-18-5/ (accessed on 24 May 2020).

Gong, Yanfen, and Xu Cao. 2014. Research on the enterprise ecological marketing effect based on fuzzy matter-element. Advanced Materials Research 962-965: 2240-44. [CrossRef]

Harini, C., S. Heru Priyanto, J. Ihalauw, and R. Kities Andadari. 2020. The role of ecological innovation and ecological marketing towards green marketing performance improvement. Management and Entrepreneurship: Trends of Development 1: 98-112. [CrossRef]

$\mathrm{Hba}$, Rachid, and Abdellah El Manouar. 2018. ICT Green Alignment: New Generation Model Based on Corporate Social Responsibility and Green IT. International Journal of Web Applications 10: 64. [CrossRef]

Henion, Karl E., and Thomas C. Kinnear, eds. 1976. Ecological Marketing. Chicago: American Marketing Association.

Huang, Shienping. 2018. Impact of internal marketing management on organizational citizenship behavior based on organizational commitment in ecological industry. Ekoloji 27: 1775-83.

Jasim, K. Mohamed, and T. Paramasivan. 2017. Ecological, green marketing and green supply chain problems-Fish marketing societies in Tamilnadu coastal areas. International Journal of Business Excellence 13: 546-62. [CrossRef] 
Kotler, Filip, and Gary Armstrong. 2012. Marketing. Warszawa: Wolter Kluwer Polska.

Kuzior, Aleksandra. 2010. Polskie i niemieckie doświadczenia w projektowaniu i wdrażaniu zrównoważonego rozwoju [Polish and German Experiences in Planning and Implementation of Sustainable Development]. Problemy Ekorozwoju—Problems of Sustainable Development 5: 81-89. Available online: http://yadda.icm.edu.pl/ yadda/element/bwmeta1.element.baztech-article-BPL2-0017-0006 (accessed on 2 October 2020).

Kuzior, Aleksandra, Aleksy Kwilinski, and Volodymyr Tkachenko. 2019. Sustainable development of organizations based on the combinatorial model of artificial intelligence. Entrepreneurship and Sustainability 7: 1353-76. [CrossRef]

Kwilinski, Aleksy, Volodymyr Tkachenko, and Aleksandra Kuzior. 2019. Transparent Cognitive Technologies to Ensure Sustainable Society Development. Journal of Security and Sustainability Issues 9: 561-70. [CrossRef]

Kwilinski, Aleksy, and Aleksandra Kuzior. 2020. Cognitive Technologies in the Management and Formation of Directions of the Priority Development of Industrial Enterprises. Management Systems in Production Engineering 28: 133-38. [CrossRef]

Kiyanivska, Natalia. 2013. Genezisponyattya «informacijno-komunikativnitexnologii». Naukovizapiski 121.

Latisheva, Olena. 2007. Etapi stanovlennya ta istorichni peredumovi formuvannya ekologichnogo marketingu. Kultura Narodov Prichernomorya 99: 71-75.

Lee, Dong H. 2007. An Alternative Explanation of Consumer Product Returns from the Postpurchase Dissonance and Ecological Marketing Perspectives. Psychology and Marketing 32: 49-64. [CrossRef]

Lindridge, Andrew, Susan MacAskill, Wendy Gnich, Douglas Eadie, and Ingrid Holme. 2013. Applying an ecological model to social marketing communications. European Journal of Marketing 47: 1399-420. [CrossRef]

Lobanova, Alla, and Luidmila Kalashnikova. 2018. Porushennya socialno-ekologichnoïrivnovagi yak zagroza bezpeci zhittediyalnosti regionalnogo sociumu (na prikladi Krivorizhzhya ta Donbasu). Religiya ta Socium:Mizhnarodnijchasopis 3-4: 31-37.

Lobanova, Alla, Vadim Bayura, Yrij Viznytsya, Luidmila Bratchenko, and Valerij Karitka. 2020. Intelligent specialization as a promising strategy for the sustainable development of industrial regions of Ukraine (the case of Kryvyi Rih industrial region). E3SWC 166: 10020. [CrossRef]

Lockrey, Simon. 2015. A review of life cycle based ecological marketing strategy for new product development in the organizational environment. Journal of Cleaner Production 95: 1-15. [CrossRef]

Malchik, Mariana, and Olena Martinyuk. 2017. Sutnist i koncepciya ekologichnogo marketingu municipalnogo utvorennya (mista). EkonomichnyjvisnykDonbasa 1: 71-81.

Melovic, Boban, Slavica Mitrovic, Biljana Rondovic, and Irina Alpackaya. 2018. Green (Ecological) Marketing in Terms of Sustainable Development and Building a Healthy Environment. Advances in Intelligent Systems and Computing 692: 1265-81. [CrossRef]

Messmer, Dean, and George Fisk. 1975. Marketing and the Ecological Crisis. Journal of Marketing 39 : 122. [CrossRef]

Metodologiya IDEF1X. Available online: https://studme.org/87187/ekonomika/metodologiya_idef1x (accessed on 10 May 2020).

Normy ISO. Available online: https://www.bsigroup.com/pl-PL/Normy/ (accessed on 10 May 2020).

Oficijnij webportal mista Kriwogo Rogu. 2020. Witkritij widobutok rud czornich metaliw. Available online: https://krmisto.gov.ua/ua/factory/list/only_type/63.html. (accessed on 24 May 2020).

Páez, Irma Ch, Ana C. Pinzón Vargas, Leonardo O. Cortázar, and Sandra P. Berrio. 2016. Scope and management of carbon footprint as a driving force of branding for companies implementing these environmental practices in Colombia. EstudiosGerenciales 32: 278-89.

Peattie, Ken. 2004. Towards Sustainability: The Third Age of Green Marketing. The Marketing Review 2: $129-46$. [CrossRef]

PolskaGrupaGórnicza. 2020. Specjaliści PGG na sesjach XXIX Szkoły Eksploatacji Podziemnej w Krakowie. Poland: Lutego, Available online: https://www.pgg.pl/aktualnosci/z-zycia-firmy/101224 (accessed on 1 May 2020).

Popescu, Ruxandra I., Razvan A. Corbos, Mihaela Comănescu, and Ovidiu I. Bunea. 2017. Ecological marketing-Strategic option for business development in Bucharest. Economic Computation and Economic Cybernetics Studies and Research 51: 67-83. 
Pozdnyakova, Ulyana A., Marina E. Buyanova, Irina M. Budanova, Tatiana L. Bezrukova, Aleksey F. Rogachev, and Vyacheslav V. Golikov. 2015. Formation of marketing strategy at environmentally determined enterprise. Mediterranean Journal of Social Sciences 6: 369-75. [CrossRef]

Sadykhanova, Gulnara, and B. Rysbayeva. 2019. Current State and Development of Ecological Marketing. National Academy of Sciences of the Republic of Kazakhstan 3: 251-58. [CrossRef]

Samal, Sarat K. 2019. Effects of green marketing on supply chain management. International Journal of Psychosocial Rehabilitation 23: 188-93. [CrossRef]

Semenov, Yurij. 2009. Cloud Computing. Available online: http://book.itep.ru/4/7/cloud.htm (accessed on 12 May 2020).

Seweryn, Renata. 2017. Technologie informacyjne i komunikacyjne. Technologie Informacyjne i Komunikacyjnena rynku Turystycznym 1: 7-24. Available online: https://www.ksiegarnia.beck.pl/media/product_custom_ files/1/6/16243-technologie-informacyjne-i-komunikacyjne-na-rynku-turystycznym-krzysztof-borodakofragment.pdf (accessed on 10 May 2020).

Shvachich, Genadij, Viktor Tolstoj, Lina Petrechuk, Yurij Ivashhenko, Olena Gulyaieva, and Oleksandr Sobolenko. 2017. Suchasniinformacijno-komunikacijnitexnologii. Dnipro: NMETU.

Sieńko, Barbara. 2000. Ekomarketing jako instrument budowania strategii przedsiębiorstwa. Prace Naukowe Akademii Ekonomicznej we Wrocławiu 870: 299-309.

Sozdanie shemy IDEF0. Available online: https://support.microsoft.com/ru-ru/office/sozdanie-shemy-idef0ea7a9289-96e0-4df8-bb26-a62ea86417fc (accessed on 12 May 2020).

Strong, Carolyn. 1997. The problems of translating fair trade principles into consumer purchase behaviour. Marketing Intelligence \& Planning 15: 32-37. [CrossRef]

Szatanowska, A., K. Kotlewska, M. Licznerska, and K. Samociuk. 2018. Trackingowe badanie swiadomosci i zachowan ekologicznych mieszkanców Polski, Ministerstwo Srodowiska. Opracowane dla Ministerstwa Środowiska przez konsorcjum firm DANAE sp. z o.o. (Lider Konsorcjum) oraz Realizacja sp. z o.o. Available online: https://sdr.gdos.gov.pl/Documents/Adaptacja/07.11.2018/20181107_Grupa\%20Adaptacja_ \%C5\%9Awiadomo\%C5\%9B\%C4\%87\%20ekologiczna\%20Polak\%C3\%B3w.pdf (accessed on 1 May 2020).

Szwed, Dariusz, and Beata Maciejewska. 2011. Zrównoważony Rozwój Metropolii Silesia. Analiza dokumentu: Strategia Rozwoju Górnośląsko-Zagłębiowskiej Metropolii „Silesia” do 2025 r. Gdańsk. Available online: www.feswar.org.pl (accessed on 1 May 2020).

Tkachenko, Volodymyr, Aleksandra Kuzior, and Aleksy Kwilinski. 2019. Introduction of Artificial Intelligence Tools into the Training Methods of Entrepreneurship Activities. Journal of Entrepreneurship Education 22: 1-10. Available online: https:/www.abacademies.org/articles/Introduction-of-artificial-intelligence-tools-15282651-22-6-477.pdf (accessed on 2 October 2020).

Tkocz, Maria. 2015. Tradycyjny okreg przemysłowy z perspektywy 25-lecia funkcjonowania w gospodarce rynkowej w Polsce. Przykład Górnośląskiego Okręgu Przemysłowego. Prace Komisji Geografii Przemysłu Polskiego Towarzystwa Geograficznego 29: 112-26. Available online: http://obserwatorium.miasta.pl/wpcontent/uploads/2017/02/Gornośląski_okrę_przemys\T1\lowy.pdf (accessed on 1 May 2020).

Turlakova, Svitlana. 2019. Informacijno-komunikacijnitehnologiyirozvitku «rozumnih» virobnictv: Naukovo-analitichnadopovid. Kyiv: NAN Ukhayini, Institut ekonomiki promislovosti, Available online: https://iie.org.ua/wp-content/uploads/2019/06/Turlakova_compressed.pdf (accessed on 1 May 2020).

Volgin, Aleksej, Ivan Gusyev, Sergej Kulikov, Sergej Mancerov, and Aleksandr Panov. 2012. Sozdanie edinogo informacionnogo prostranstva mashinostroitelnogo predpriyatiya na osnove "oblachnyh" tehnologij. Vestnik VGTU 6: 44-47.

Wang, Zheng, and Linxue Wang. 2019. Research on ecological marketing strategy of modern enterprises-take MI company as an example. Ekoloji 28: 3593-603. Available online: http://ekolojidergisi.com/download/researchon-ecological-marketing-strategy-of-modern-enterprises-take-mi-company-as-an-example-6002.pdf (accessed on 1 May 2020).

Wojnicka-Sycz, Elżbieta. 2013. Narzędzia ICT wspierające proces innowacyjny. Zarządzanie i Finanse 1: $403-17$. Available online: http://zif.wzr.pl/pim/2013_4_1_31.pdf (accessed on 20 May 2020). 
Yu, Kaijun, Jun Ying, Qiaoli Tian, Longjie Sun, and Gang Huang. 2019. Measure of input/output efficiency of the introduction of digital marketing into green products in ecological industry. Journal of Environmental Protection and Ecology. Special Issue A 20: S346-S354.

Zaremba-Warnke, Sabina. 2009. Marketing Ekologiczny. Wrocław: Wydawnictwo Uniwersytetu Ekonomicznego.

Publisher's Note: MDPI stays neutral with regard to jurisdictional claims in published maps and institutional affiliations.

(C) 2020 by the authors. Licensee MDPI, Basel, Switzerland. This article is an open access article distributed under the terms and conditions of the Creative Commons Attribution (CC BY) license (http://creativecommons.org/licenses/by/4.0/). 